DOI: 10.35757/RPN.2010.18.02

Jerzy Eisler

\title{
ROK 1968 W POLSCE - KRYZYS WŁADZY, KRYZYS SPOŁECZEŃSTWA, POCZĄTEK PRZEMIAN?
}

Rok 1968 to jedna z najważniejszych dat w dziejach nie tylko Polski, ale także Europy i świata po II wojnie światowej. Wyznaczają go przede wszystkim tak różnorodne wydarzenia i zjawiska społeczne jak, z jednej strony, Praska Wiosna, brutalnie stłumiona przez wojska Układu Warszawskiego, z drugiej zaś fala młodzieżowej kontestacji na Zachodzie, która najbardziej hałaśliwe, ale już nie najbardziej dramatyczne oblicze przybrała we Francji, Republice Federalnej Niemiec i Stanach Zjednoczonych. Rok 1968 wyznaczał również apogeum wojny w Wietnamie, a także był ważnym etapem $\mathrm{w}$ radziecko-chińskiej rywalizacji o dominującą pozycję w „rodzinie komunistycznej”.

Również w Polsce mieliśmy do czynienia ze złożonymi i skomplikowanymi procesami społecznymi. Chciałbym się zatem zastanowić, czy miał tutaj wówczas miejsce kryzys społeczny, a jeżeli tak, to jakie było jego podłoże i jakie były jego cechy charakterystyczne? Czy można zatem i należy mówić o kryzysie ówczesnej władzy i co to w ogóle znaczyło w rzeczywistości realnego socjalizmu? Wreszcie, warto zastanowić się, czy w wypadku Polski można uznać, iż rok 1968 wyznaczał początek zmian systemowych?

Chociaż na temat wydarzeń, które utarło się w Polsce określać mało precyzyjnym i niewiele mówiącym pojęciem Marzec '68, opublikowano 
już ponad 50 książek $^{1}$ o różnej wartości i rozmaitym charakterze, to nadal wiele kwestii pozostaje nie do końca wyjaśnionych i budzi wśród historyków kontrowersje. Przede wszystkim należy wyraźnie stwierdzić, że raczej powinniśmy posługiwać się niepoprawnym z logicznego punktu widzenia określeniem „Marce '68” (w liczbie mnogiej, a nie pojedynczej), gdyż pod pojęciem tym kryło się kilka różnych, niekoniecznie ze sobą powiązanych, a niekiedy wręcz wykluczających się i przeciwstawnych nurtów.

Cóż bowiem w istocie łączyło protesty polskiej młodzieży, występującej z wolnościowymi hasłami z równoległą w czasie falą antysemityzmu w środkach masowego przekazu? A co miała wspólnego brutalna antyinteligencka kampania w mediach z zakulisowymi rozgrywkami politycznymi w kierownictwie Polskiej Zjednoczonej Partii Robotniczej? We wszystkich tych wypadkach w praktyce wspólne były tylko dwa czynniki: czas (wiosna 1968 roku) i miejsce analizowanych wydarzeń (Polska). Co więcej, w zależności od tego, kto i w jakim celu spoglądał później na Marzec, wydobywał z niego przede wszystkim te wątki, które w największym stopniu dotyczyły jego samego i środowiska, w którym wtedy się obracał.

Zrozumiałe jest więc, że osoby, które po Marcu wyemigrowały z Polski, jak i ich bliscy, którzy pozostali w kraju, najczęściej wspominają haniebną "kampanię antysyjonistyczną" - jak nieudolnie kamuflowano wówczas antysemityzm. Trudno zaprzeczyć, że antysemici w wielu krajach byli, są i zapewne w jakiejś skali zawsze (w dającej się realnie przewidzieć przyszłości) będą się pojawiać, ale w Europie po Shoah trudno było z takimi hasłami występować otwarcie. W państwach demokratycznych zwykle antysemici plasowali się więc na marginesie głównego nurtu życia publicznego, szukając jakichś niszowych wydawnictw i propagując swoje hasła anonimowo. W rządzonej przez komunistów Polsce, gdzie istniała prewencyjna cenzura i policja polityczna, publikowanie tekstów antysemickich było ustawowo zakazane.

1 J. Eisler: Stan badań historycznych nad Marcem '68, „Dzieje Najnowsze” 2008, nr 1, s. 7-17. W poświęconym rokowi 1968 numerze tematycznym „Dziejów Najnowszych" omawiam stan badań, doprowadzając przegląd literatury przedmiotu do końca 1967 roku. W związku z czterdziestą rocznicą Marca w ciągu zaledwie kilkunastu następnych miesięcy ukazało się w Polsce ponad 20 nowych publikacji książkowych na ten temat. 
Jednak w 1968 roku to właśnie za sprawą rządzących antysemityzm trafił na pierwsze strony gazet oraz do głównych wydań serwisów informacyjnych radia i telewizji. Zresztą w Ministerstwie Spraw Wewnętrznych już od początku lat sześćdziesiątych systematycznie narastało specyficzne zainteresowanie społecznością żydowska, chociaż w połowie dekady mieszkało w Polsce nie więcej niż 30 tys. Żydów oraz Polaków pochodzenia żydowskiego ${ }^{2}$. Przede wszystkim więc "polowano" na "syjonistów" na eksponowanych stanowiskach, z których można by ich ewentualnie usunąć i zająć je samemu lub powierzyć komuś zaufanemu. W konsekwencji tej antysemickiej „czystki”, która objęła aparat partyjny i administrację państwową, świat nauki, kultury i sztuki, media, wojsko, a wcześniej dopełniła się w szeroko rozumianym aparacie bezpieczeństwa, wiele osób na kierowniczych stanowiskach usunięto wtedy z partii i z pracy.

Wymusiło to na licznych z nich podjęcie decyzji o wyjeździe z Polski na stałe. W latach 1968-1972 wyemigrowało ponad 15 tys. osób. Była to już trzecia - najmniej liczna, ale chyba za to najgłośniejsza - fala emigracji żydowskiej z powojennej Polski. O randze tej emigracji stanowiła jednak nie jej liczebność, lecz przede wszystkim fakt, iż wśród 9570 osób dorosłych ubiegających się wówczas o wyjazd, wyższym wykształce-

2 Wypada tutaj przypomnieć, że Holocaust położył kres wielowiekowej obecności Żydów na ziemiach polskich. Przed II wojną światową mieszkało tutaj około 3,5 mln osób wyznania mojżeszowego. Trudno precyzyjnie określić, jak liczna była grupa tych, którzy ocaleli z Pogromu. Wedle rozmaitych szacunków łączna liczba ludności żydowskiej w Polsce bezpośrednio po wojnie miała się wahać między 200 a 400 tys. osób. Tak duża rozpiętość brała się m.in. z tego, że gdy jedni Żydzi wracali z obozów bądź byli przesiedlani ze Związku Radzieckiego do Polski w jej nowych granicach, w tym samym czasie inni - w mniej lub bardziej legalny sposób - z niej wyjeżdżali, gdyż nie chcieli żyć dłużej w kraju, który uważali za jedno wielkie żydowskie cmentarzysko. Według danych Centralnego Komitetu Żydów w Polsce (CKŻP) w początku 1946 roku liczba ludności żydowskiej wynosiła zaledwie 93 tys., ale w następnych miesiącach w zorganizowanych transportach przesiedlono z ZSRR do Polski w jej nowych granicach 136,5 tys. Żydów i osób żydowskiego pochodzenia. W efekcie w końcu czerwca 1946 roku - wedle danych CKŻP - liczba ludności żydowskiej miała wynosić ok. 240 tys. osób. W następnych tygodniach i miesiącach (głównie po pogromie w Kielcach) nasiliły się jednak wyjazdy Żydów z Polski. Ostatecznie jesienią 1948 społeczność żydowska w Polsce liczyła ok. 100 tys. osób, a do 1951 roku, kiedy władze zabroniły emigracji do Izraela, skurczyła się do niespełna 80 tys. Szerzej zob.: A. Stankowski: Nowe spojrzenie na statystyki dotyczace emigracji Żydów z Polski po 1944 roku, w: G. Berendt, A. Grabowski i A. Stankowski: Studia z historii Żydów w Polsce po 1945 roku, Warszawa 2000, s. 108-109, 150. 
niem legitymowały się 1823 osoby, a dalsze 944 studiowały. W gronie osób pragnących wtedy emigrować do Izraela (można było podać tylko taki cel wyjazdu, nawet jeżeli składający podanie w ogóle nie zamierzał tam jechać) znalazło się 217 byłych pracowników szkół wyższych i 275 osób pracujących wcześniej w różnego rodzaju instytutach naukowych ${ }^{3}$.

Za sprawą tej fali emigracyjnej ogromne straty poniosła również polska kultura. Była to bowiem emigracja o obliczu wyraźnie inteligenckim. Nie wolno też jednak zapominać, że nie wszystkie osoby ubiegające się o zgodę na wyjazd otrzymywały ważny tylko w jedną stronę "dokument podróży", choć - przyznać trzeba - że decyzji odmownych było relatywnie niewiele. Natomiast na podkreślenie zasługuje fakt, że - wbrew utartym propagandowym schematom - nie była to emigracja syjonistyczna. Ci, którzy chcieli wyjechać do Izraela z pobudek syjonistycznych, na ogół uczynili to wcześniej.

Abstrahując od innych względów, należy zwrócić uwagę na to, że organizujący w 1968 roku antysemicką kampanię partyjni działacze zapewne nie zastanawiali się nad tym, jak - w 25 lat po zrealizowanej przez niemieckich nazistów na ziemiach polskich Zagładzie - tego typu akcja zostanie odebrana przez międzynarodową opinię publiczną. A odbiór ten na Zachodzie był jednoznacznie zły i wywołał tam falę protestów i gestów solidarności ze społecznością żydowską w Polsce. Nie wszystkie zarzuty były zresztą słuszne i sprawiedliwe. Na pewno nie służyły zbliżaniu się do prawdy wszelkie krzywdzące generalizacje i uproszczenia.

Niemniej jednak trzeba przyznać, iż niemała część z ówczesnych emigrantów jak gdyby uwierzyła propagandzie podważającej ich prawo do polskości. Wielu z tych, którzy przed 1968 rokiem uważali się za Polaków i deklarowali przywiązanie do polskości, później nierzadko wolało mówić o sobie: „jestem z Polski” niż ,jestem Polakiem”. Niektórzy emigranci, pochodzący z rodzin od dawna już zasymilowanych, właśnie w 1968 - w obliczu kampanii antysemickiej - otwarcie nawiązywali i wracali do swoich żydowskich korzeni. Inni z wolna przestawali się czuć Polakami, ale przez to niekoniecznie rosło ich poczucie żydowskości.

\footnotetext{
3 J. Eisler: Polski rok 1968, Warszawa 2006, s. 130-131.
} 
Skoro emigracja pomarcowa miała charakter inteligencki, to trudno się dziwić, że właśnie $\mathrm{w}$ tych środowiskach pamięć o wydarzeniach roku 1968 jest szczególnie żywa. Dla wielu ludzi ze świata kultury, nauki i sztuki nawet po ponad 40 latach jawią się one głównie jako antyinteligencki pogrom, kiedy to $\mathrm{w}$ środkach masowego przekazu z niezwykłą brutalnością atakowano wymienianych z imienia i nazwiska pisarzy i naukowców, nierzadko o ogromnych dokonaniach i zasługach. Gdy dziś przegląda się ówczesną polską prasę, zdumiewa fakt, ile miejsca poświęcano wtedy niepokornym intelektualistom, przy czym cechą wspólną wszystkich tych publikacji było to, że w ślad za partyjnymi działaczami odmawiały one atakowanym nie tylko walorów ideowo-moralnych, ale niejednokrotnie także zawodowych kwalifikacji.

Jednocześnie na powierzchnię życia umysłowego wypływali wówczas ludzie nowi, którzy bardzo często szybkie awanse zawdzięczali nie zdolnościom i pracowitości, lecz politycznej dyspozycyjności. W tym samym czasie liczne książki, których autorów władze uznawały za niepokornych, niezależnie od stopnia zaawansowania, zostały wstrzymane: poszły na przemiał lub rozsypano gotowy już skład. Cenzura zatrzymywała filmy uznawane przez władze za "antypolskie”, a nawet wycofała z kin wprowadzony na ekrany zaledwie parę tygodni wcześniej zrealizowany w koprodukcji z producentem zachodnioberlińskim obraz Jana Rybkowskiego Rassenschande - kiedy miłość była zbrodnia. Film ten opowiadał o zakazanych przez nazistowskie prawodawstwo związkach erotycznych Niemców z ludźmi innych narodowości i ras. Trudno orzec, co było $w$ tym wypadku gorsze $z$ punktu widzenia ówczesnych władz: współpraca z niemieckim producentem czy też „kontrowersyjny" (w klimacie Marca) sam temat tego filmu.

Nie jest chyba dziełem przypadku, że (obok stanu wojennego) właśnie schyłkowy okres rządów Władysława Gomułki, czyli lata 1968-1970 powszechnie uznawane są za okres najbardziej ponury w postalinowskiej Polsce. Jego dziedzictwem było także i to, że np. Leszek Kołakowski, jeden z najwybitniejszych współczesnych filozofów, dopiero od roku 1989 mógł zacząć przyjeżdżać do Polski, a jego prace ponownie zostały włączone do oficjalnego obiegu naukowego. To samo dotyczyło Zygmunta Baumana, Bronisława Baczki, Włodzimierza Brusa, Krzysztofa 
Pomiana i innych uczonych, którzy po Marcu wyemigrowali z Polski. W sumie od pracy dydaktycznej odsunięto prawie 70 profesorów i docentów (najwięcej w Warszawie), nierzadko o znanych nazwiskach i dużym autorytecie $\mathrm{w}$ środowisku.

Mimo że naturalnie nie wszyscy oni wyjechali z kraju, to jednak i tak polska nauka poniosła niepowetowane straty, tym bardziej że czystkom tym towarzyszyły liczne awanse "marcowych docentów”. Byli to na ogół ludzie mierni, którzy brak habilitacji i wystarczającego dorobku naukowego nadrabiali serwilizmem i polityczną dyspozycyjnością a którzy przez następne lata niejednokrotnie dyrygowali życiem naukowym w Polsce. W skali kraju dokonano 575 tego typu awansów na ogólną liczbę niemal 4,5 tys. samodzielnych pracowników naukowych. Nie przedłużono także kadencji $26 \%$ dotychczasowych rektorów i $62 \%$ prorektorów ${ }^{4}$.

Na uczelniach i w Polskiej Akademii Nauk zostały też dokonane restrykcyjne czystki, w których wyniku usunięto wielu młodych, zdolnych, zaczynających dopiero kariery naukowe badaczy, z których przynajmniej część mogłaby znakomicie się rozwinąć. Trzeba jednak również pamiętać, że Marzec dostarczył doświadczeń późniejszym ruchom i działaczom opozycyjnym. Przede wszystkim w Polsce bodaj po raz pierwszy tak dobitnie wykazał niereformowalność systemu. Od tej pory młode, ukształtowane już w powojennej Polsce pokolenie, które w roku 1968 upominało się w imię socjalizmu o utracone wartości, zaczęło pozbywać się złudzeń.

Dla ludzi z tego właśnie pokolenia, którzy w 1968 roku studiowali, nawet po latach najważniejszy pozostaje studencki nurt Marca. W pamięć tych osób przeważnie najmocniej wryły się wiece, strajki i manifestacje studenckie. Wielu postrzega Marzec jako wydarzenie, które $\mathrm{w}$ istotnym stopniu wpłynęło na ich dalsze życie. Zresztą ten właśnie nurt „wydarzeń marcowych” znany jest dzisiaj chyba najlepiej. Wiemy, że studenci kontestujący w Polsce występowali pod hasłami wolnościowymi, odwołując się do lewicowej frazeologii. Być może w swoich ulotkach i rezolucjach przyjmowanych na wiecach posługiwali się ofi-

\footnotetext{
4 Ibidem, s. 614.
} 
cjalnym językiem, licząc na to, że dzięki temu będzie to lepiej przyjęte przez rządzących i łatwiej będzie im w ten sposób dotrzeć do nich. Jeżeli tak było rzeczywiście, to chyba dość naiwnie odczytywali istotę systemu komunistycznego i nie rozumieli, że walcząc w pierwszej kolejności o demokratyzację i liberalizację systemu, a także o prawo do życia w prawdzie, w istocie - chcąc nie chcąc - występowali przeciwko temuż systemowi. Wydaje się, że do końca nie zrozumieli jak bardzo antysystemowe było jedno $\mathrm{z}$ ich najbardziej wówczas popularnych haseł: „Prasa kłamie!”

„Wydarzenia marcowe” przyczyniły się także do uformowania czegoś, co można umownie nazwać "pokoleniem '68”. Trzeba jednak wyraźnie podkreślić, że w odróżnieniu od Czechosłowacji, gdzie pojęciem tym określano głównych aktorów Praskiej Wiosny, takich jak Alexander Dubček, Zdeněk Mlynař czy Josef Smrkovský, mających w 1968 roku 40-50 lat, to w Polsce do "pokolenia '68” zalicza się dwudziestolatków, będących wtenczas na studiach. Wielu $\mathrm{z}$ nich $\mathrm{w}$ drugiej połowie lat siedemdziesiątych działało $\mathrm{w}$ antykomunistycznej opozycji, zaś po fali strajków z lata roku 1980 znalazło się wśród działaczy i doradców „Solidarności". Natomiast po zmianie w Polsce ustroju wielu pełniło różne odpowiedzialne funkcje publiczne, będąc posłami, senatorami, ministrami itd. Osoby te często uznają Marzec za najważniejsze doświadczenie życiowe, a prawdę za najważniejszą w wyznawanym systemie wartości.

$\mathrm{Na}$ marginesie warto zwrócić uwagę na fakt, że stosunkowo często podejmowano próby porównywania „wydarzeń marcowych" - w ich studenckim wymiarze - do fali młodzieżowej kontestacji, jaka przetoczyła się przez świat w 1968 roku. Wszelako - mimo wszelkich zewnętrznych podobieństw (strajki na uczelniach, manifestacje, wiece, starcia uliczne z "siłami porządkowymi") - ówczesne wydarzenia w Polsce można by ewentualnie porównywać jedynie z Praską Wiosną i z ruchem reformatorskim w Czechosłowacji. Studenci zachodnioniemieccy, włoscy, francuscy, amerykańscy itd. występowali bowiem przeciwko instytucjom państwa, funkcjonującego przecież w zupełnie innym kształcie.

W przeciwieństwie do studentów polskich i czechosłowackich nie musieli walczyć o wolność słowa i swobodę zgromadzeń, gdyż nale- 
żały one do fundamentalnych zasad państwa demokratycznego. Zresztą protesty studentów na Zachodzie w znacznym stopniu miały charakter środowiskowy. Na przykład we Francji młodzież, choć jej protesty doprowadziły do strajku generalnego i poważnego kryzysu władzy, walczyła przede wszystkim o szeroko rozumianą reformę szkolnictwa wyższego, podczas gdy w Polsce i Czechosłowacji protesty studenckie miały charakter ogólnospołeczny, ponieważ głównym celem studentów w tych krajach była liberalizacja systemu.

Ruch kontestacyjny na Zachodzie, mający najczęściej lewacki charakter, był więc jakościowo innym zjawiskiem. Zresztą nie można go traktować w sposób jednolity. Istniała wszak kluczowa różnica między paryskim majem w Dzielnicy Łacińskiej z demolowaniem sklepów i samochodów, barykadami i zajściami ulicznymi, podczas których na szczęście nie było ofiar śmiertelnych, a tym, co zdarzyło się w październiku 1968 roku w Mexico City ${ }^{5}$, gdzie demonstrację studencką zaatakowało wojsko z bagnetami na karabinach, którymi dźgano protestujących, kiedy to walono ich kolbami od karabinów i ostrzeliwano ze śmigłowców. Rok 1968 - rozpatrywany w kontekście młodzieżowej kontestacji - wiąże się więc $\mathrm{z}$ bardzo różnymi wydarzeniami, które w zasadzie łączyło tylko to, że za każdym razem był to bunt młodych, o innym jednak podłożu, ideologii i często przebiegu.

Niemniej jednak nie wolno zapominać, że - mimo tych wszelkich istotnych różnic - w maju 1968 roku studenci francuscy starali się podkreślać więź z polskimi kolegami, skandując: „Rome, Berlin, Varsovie, Paris!". Dodać także należy, że do najpopularniejszych wtedy lektur na Sorbonie należało francuskie tłumaczenie Listu otwartego do Partii autorstwa Jacka Kuronia i Karola Modzelewskiego ${ }^{6}$. Wreszcie warto przypomnieć, że Daniel Cohn-Bendit, gdy był przesłuchiwany i w kółko pytany o swoje nazwisko, po kilku prawidłowych odpowiedziach nie wytrzymał i zapytany po raz nie wiadomo który o to samo wypalił: „Kuroń-Modzelewski”.

5 Szerzej zob. M. Kula: Studenci jako grupa rewoltogenna, w: Oblicza Marca 1968..., s. 226. Zob. też D. Warszawski: Życie da się zmienić, "Gazeta Wyborcza”, $24-25$ maja 2003; M. Żurek: „Do diabła z ludem i historia”, „Tygodnik Powszechny” 2003, nr 40.

6 A. Paczkowski: 1968: Marzec kontra Maj?, „Krytyka” 1988, nr 28-29, s. 52-59. 
Warto zatem na pewno wskazać na dwie zasadnicze różnice. Po pierwsze, studenci we Francji, RFN, Włoszech, a zwłaszcza w Stanach Zjednoczonych mogli być pewni, że ich protest będzie szeroko odnotowany przez tamtejsze środki masowego przekazu, a nawet obdarzony życzliwością. Polscy studenci, żyjąc w kraju, gdzie jedynym niemal właścicielem i dysponentem środków masowego przekazu było państwo, nie tylko nie mogli na to liczyć, ale - co więcej - sami musieli się przeciwstawiać dezinformacji, kłamstwom i oszczerstwom na łamach prasy, w radiu i telewizji.

Środki masowego przekazu w Polsce brały udział w obrzydliwej kampanii nie tylko antysemickiej i antyinteligenckiej, lecz także antystudenckiej. W mediach wypaczano sens protestu młodych ludzi, którzy - powołując się na Konstytucję PRL - domagali się przestrzegania wolności słowa i wolności zgromadzeń. Ich żądania zostały jednak skarykaturowane, ośmieszone i nazwane działaniami tajemniczych wichrzycieli, inspiratorów i bankrutów politycznych. Przywódcy studenccy na Zachodzie z dnia na dzień stawali się bohaterami tłumów, nierzadko swoją popularnością dystansując gwiazdy estrady i sportu ${ }^{7}$ W Polsce trafiali do więzień $w$ atmosferze nagonki i zaszczucia.

Po drugie, w państwach o zinstytucjonalizowanym politycznym pluralizmie, w który wmontowane zostały liczne kanały służące wyładowaniu i ekspresji społecznego protestu, ruch studencki - jak pisał przed laty Zygmunt Bauman - był jeszcze jedną droga dodatkowym ujściem „wyprowadzającym na powierzchnię życia politycznego nowe zasoby protestu, dotąd nie ujawnione, ale nie jedyne, nie radykalnie nowe, nie niecodzienne i nie wyjątkowe w systemie społecznym, którego istotą jest instytucjonalizacja konfliktów i sposobów ich rozwiązywania" $^{8}$. Ruch studencki mógł więc w znacznej mierze pozostać ruchem studenckim i ograniczyć się do formowania własnych postulatów

\footnotetext{
7 We Francji widziałem film dokumentalny na temat 1968 roku, w którym prezentowano jak to Daniel Cohn-Bendit szedł otoczony przez grupę dziennikarzy z mikrofonami oraz kilka kamer telewizyjnych i głośno śpiewał Międzynarodówkę. Od razu pomyślałem, że w Polsce taka scena, np. z udziałem Jacka Kuronia czy Adama Michnika, byłaby niemożliwa i to nie tylko dlatego, że w 1968 roku pewnie nie śpiewaliby już tej pieśni, ale dlatego, że nikt nie pokazałby tego.

8 Z. Bauman: O frustracji i o kuglarzach, „Kultura” (Paryż) 1968, nr 12, s. 16-17.
} 
akademickich. Odmiennie było w Polsce, gdzie buntująca się młodzież występowała - w jakimś przynajmniej stopniu - w imieniu całego społeczeństwa.

Trzeba przy tym pamiętać, że było to pierwsze pokolenie urodzone i wychowane już w Polsce rządzonej przez komunistów. W połowie lat sześćdziesiątych $\mathrm{w}$ dorosłe życie zaczęło bowiem wkraczać pokolenie powojennego wyżu demograficznego (baby boom). Punktem odniesienia dla aspiracji i oczekiwań tych młodych ludzi z oczywistych powodów nie mogła być Polska sprzed II wojny światowej, której nie znali z autopsji, ale poznawane głównie z filmów, książek, prasy młodzieżowej, a także za sprawą coraz bardziej popularnej telewizji kraje zachodnie. Ci młodzi ludzie - na miarę ograniczonych w systemie komunistycznym możliwości - starali się wyglądać jak ich rówieśnicy na Zachodzie: chłopcy próbowali grać na gitarach i nosili długie włosy, a dziewczyny krótkie sukienki i spódnice. Jedni i drudzy słuchali anglojęzycznych piosenkarzy i zespołów rockowych, szczególnie często za pośrednictwem legendarnego Radio Luxemburg.

Nie od rzeczy będzie tutaj przypomnieć, iż przez długie lata powszechnie uważano w Polsce, że protesty w 1968 roku w naszym kraju miały charakter jednoznacznie studencki i inteligencki. Obecnie wiemy już jednak, że traktowanie fali młodzieżowej kontestacji wyłącznie jako ruchu studenckiego jest poważnym błędem. Nawet jeżeli - co nie ulega wątpliwości - studenci stanowili siłę napędzającą ówczesne protesty, to przecież nie miały one wąsko rozumianego charakteru akademickiego i wykraczały daleko poza kwestie nurtujące wyłącznie to środowisko. Studenci przemawiali wtenczas w imieniu całego niemal społeczeństwa, upominając się o sprawy natury zasadniczej ważne nie tylko dla nich, lecz dla ogółu Polaków.

Wszelako nie wolno także zapominać, że w wielu wypadkach $\mathrm{w}$ ulicznych demonstracjach brali udział również młodzi robotnicy czy też młodzież szkolna. Trudno też pominąć milczeniem fakt, że do ulicznych wystąpień i gwałtownych starć z "siłami porządkowymi" dochodziło także w miastach, w których w 1968 roku nie było jeszcze szkół wyższych: Bielsku-Białej, Legnicy, Radomiu i Tarnowie. W ogóle należy podkreślić, że najróżniejsze wypadki solidaryzowania 
się ze studentami np. w postaci kolportażu „wrogich ulotek” bądź sporządzania w miejscach publicznych „wrogich napisów” Służba Bezpieczeństwa odnotowała w kilkuset (sic!) miejscowościach na terenie całego kraju.

Wielu ludziom jeszcze i dziś trudno jest uwierzyć, że zdecydowanie najliczniejszą grupę zatrzymanych w Marcu 1968 stanowili robotnicy, a nie studenci. Oczywiście nie wolno przy tym zapominać, że w ówczesnej Polsce tych pierwszych było kilkanaście razy więcej. Niemniej jednak według danych MSW, od 7 marca do 6 kwietnia w całym kraju zatrzymano 2725 osób, w tym 937 robotników - o ponad 300 więcej niż studentów. W świetle przytoczonych tu liczb trudno podtrzymywać tezę o pasywnej postawie tych pierwszych w czasie „wydarzeń marcowych".

Bardzo odpowiada mi zatem teza, którą kiedyś niezależnie od siebie sformułowali Andrzej Friszke i Marcin Zaremba. Ten pierwszy na podstawie zacytowanych przed chwilą danych postawił nawet pytanie, czy nie należałoby zakwestionować zdania głoszącego, iż robotnicy pozostali w Marcu bierni, choć przecież „nie wystąpili jako grupa społeczna, nie działali na terenie swoich fabryk, występowali indywidualnie lub w małych grupach jako cząstka tłumu w czasie ulicznych demonstracji. Była to wszakże cząstka pokaźna" ${ }^{\prime 9}$.

Z kolei Marcin Zaremba zwrócił uwagę na to, że „wszyscy wymienieni $\mathrm{w}$ raportach zatrzymani robotnicy byli młodzi lub bardzo młodzi. Mieli nie więcej niż trzydzieści lat. Sugerowałoby to, iż w Marcu 1968 r. mieliśmy raczej do czynienia $\mathrm{z}$ ruchem, którego jedną z istotniejszych spójni była więź pokoleniowa. Innymi słowy, to nie robotnicy się ruszyli, tylko młodzież"10.

Jest to niezwykle interesujące i ważne stwierdzenie. Młodzi robotnicy często byli dla studentów po prostu kolegami ze szkoły podstawowej, z podwórka, drużyny harcerskiej czy klubu sportowego. Przy analizowaniu tego problemu nie wolno także zapominać o młodzieży

9 A. Friszke: Ruch protestu w marcu 1968 (w świetle raportów MSW dla kierownictwa PZPR), „Więź" 1994, nr 3, s. 91.

${ }^{10}$ M. Zaremba: Biedni Polacy 68. Społeczeństwo polskie wobec wydarzeń marcowych $w$ świetle raportów KW i MSW dla kierownictwa PZPR, w: Marzec 1968. Trzydzieści lat później, t. 1: Referaty, red. M. Kula, P. Osęka i M. Zaremba, Warszawa 1998, s. 159. 
ze szkół ponadpodstawowych, w tym także - a może nawet przede wszystkim - z przyzakładowych techników i zasadniczych szkół zawodowych. Wszystkich tych młodych ludzi nierzadko łączył swoisty generacyjny kod kulturowy: słuchali tej samej muzyki, często podobnie się ubierali, nierzadko nosili długie włosy, chodzili na te same filmy, niejednokrotnie wspólny im był bunt pokoleniowy.

Dwudziestoletni robotnik nie odczuwał praktycznie żadnej więzi ze swoim o dwadzieścia lat starszym kolegą z pracy, miał ją natomiast ze studentem. Należy więc mówić raczej o pokoleniowym buncie: młodych robotników, studentów i uczniów szkół średnich, którzy wyszli na ulicę. Znacznie trudniej było porwać ludzi starszych, gdyż nie tylko znali z autopsji i pamiętali, ale niejednokrotnie mieli na własnych plecach zapisany stalinizm. Żywy pozostawał w nich strach przed wszechmocnym kiedyś „personalnym” w zakładzie pracy. Wiedzieli, że nie warto się wyróżniać. Młodzi takiej świadomości nie mieli, odrzucali tę strategię. Uważali, że trzeba coś robić, gdy komuś dzieje się krzywda, trzeba protestować i niegodziwości nazywać po imieniu.

Jak już wspomniano, dla tych młodych ludzi punktem odniesienia nie mogła już być przedwojenna Polska (będąca nim jeszcze dla wielu przedstawicieli starszego pokolenia), ale „kraje kapitalistyczne”, poznawane za pośrednictwem telewizji, zachodnich filmów i opowiadań ludzi, którzy je widzieli na własne oczy (np. marynarzy) ${ }^{11}$. Warto także pamiętać, że rewolucje, powstania, rewolty, bunty zawsze i wszędzie były dziełem ludzi młodych. Historia nie zna rewolucji czy buntu pięćdziesięciolatków, choć właśnie oni mogą być - i zwykle są - przywódcami, ideologami, dowódcami. Składa się na to zresztą wiele czynników.

Po pierwsze, ludzie młodzi angażujący się $\mathrm{w}$ akcje protestacyjne często nie zdają sobie do końca sprawy $\mathrm{z}$ wiążącego się $\mathrm{z}$ tym ryzyka, co jest także konsekwencją właśnie braku tego typu doświadczeń. Po drugie, młodzież zwykle cechuje bezkompromisowość i radykalizm.

\footnotetext{
${ }^{11}$ Gdy w drugiej połowie lat sześćdziesiątych I sekretarz KC PZPR Władysław Gomułka uskarżał się publicznie na to, że gdy on przed wojną był robotnikiem, to posiadał zaledwie dwie koszule, podczas gdy współcześni robotnicy mają na pewno przynajmniej po cztery, to tego typu argumentacja działała jeszcze na wyobraźnię starszych robotników, nierzadko dobrze pamiętających biedę w przedwojennej Polsce, ale kompletnie nie docierała już do osób młodych.
} 
Mniej u niej miejsca na kunktatorstwo, a nawet na chłodny namysł. Po trzecie, łatwiej jest uczestniczyć w starciach ulicznych (ucieczkach przed policją, rzucaniu kamieniami, nierzadko walce wręcz) wymagających znacznej sprawności fizycznej, gdy ma się lat dwadzieścia niż pięćdziesiąt czy więcej.

W 1968 roku mieliśmy jednak w Polsce do czynienia nie tylko z „rewolucją dwudziestolatków”, ale równoległą w czasie drugą "rewolucją czterdziestolatków". Jej siłą sprawczą byli ambitni, stosunkowo młodzi (właśnie około czterdziestoletni) działacze partyjni i państwowi średniego i niższego szczebla, coraz częściej dobierani - wedle dominującej w PRL - zasady BMW (bierny, mierny, ale za to wierny). Liczyli oni na to, że w wyniku sztucznie wytworzonego „ruchu kadrowego" będą mogli wreszcie awansować.

Socjolog Zygmunt Bauman już po wyjeździe z Polski, jesienią 1968 roku, tak opisywał sytuację społeczną $\mathrm{w}$ kraju w przededniu Marca: „Milcząca, ale tajemnicza i mająca dość powodów do niezadowolenia klasa robotnicza, naładowana dynamitem młodzież, rozgoryczone środowiska intelektualne i sfrustrowana nowa klasa średnia, ów rdzeń »ludowej« władzy, a nad tym wszystkim przerażona, niepewna wszystkich i wszystkiego góra partyjna - oto [...] sytuacja, którą wedle wszelkich zasad leninowskiej analizy określić wypada jako rewolucyjną"12.

W tej trafnej analizie sytuacji w Polsce u schyłku 1967 roku Bauman posłużył się określeniem „nowa klasa średnia”, w której frustracjach skłonny był upatrywać jedną z głównych przyczyn marcowego wybuchu. „W wyniku rewolucyjnych przeobrażeń z okresu początków władzy ludowej drabina w wielu urzędach polskich, w kaście oficerskiej i na średnich szczeblach aparatu partyjnego jest nader spłaszczona i problem awansu - najbardziej dotkliwy z problemów każdej biurokracji - nie może być rozwiązywany w Polsce przy pomocy automatycznego mechanizmu »wysługi lat«. W dawnych latach rozwiązywano więc ten problem za pomocą bądź masowych czystek, bądź sztucznego rozdmuchiwania etatów. Od dwunastu lat nie stosowano w Polsce ani jednej, ani drugiej metody. Okres dostatecznie długi, by nagromadziły

\footnotetext{
${ }^{12}$ Bauman: op. cit., s. 13-14.
} 
się spore zastępy ambitnych i sfrustrowanych”. Wyposażony w „wątłe podstawy własnego bezpieczeństwa urzędnik nie mógł być pewien swego losu w obliczu potężniejących zastępów nieusatysfakcjonowanych konkurentów.

Dotyczy to zwłaszcza szczególnego odłamu nowej klasy średniej - złożonego z ludzi bez dyplomów i bez systematycznych kwalifikacji zawodowych i zawdzięczających swą pozycję osiągnięciom nie związanym z pragmatyką wykonywanego zawodu. $Z$ tych, którzy brak wiedzy fachowej łatali nadmiarem posłuszeństwa i wierności dla władzy"13. Żeby wywołać pożądany przez nich ruch kadrowy, potrzebny był jeszcze jakiś pretekst.

Obrazowo ujął to dziennikarz i krytyk teatralny Andrzej Wróblewski, którego zdaniem Marzec był niewątpliwie reakcją na długi zastój, także kadrowy. Opisał ówczesną sytuację, posługując się plastycznym porównaniem: „Wiadomo, że śmiecie czekają na wiatr, który by je wzniósł w górę; to dla nich jedyna szansa. Ale młodzi zdolni również czekali, aż wymrą stare niezdarne pierdoły. Była więc potrzeba zmian. Ten ustrój nie znał mechanizmów zmiany, nie tylko na szczycie. Sprawa żydowska była więc instrumentalna, wywoływała inne szersze procesy. Ofiarami tego sztucznego wiatru padali również ludzie, którzy nic z żydostwem nie mieli wspólnego" ${ }^{14}$.

Wspomnianym nurtom Marca towarzyszyła walka kierownictwa partyjnego z opowiadającymi się konsekwentnie za liberalizacją i demokratyzacją systemu "rewizjonistami” wśród intelektualistów, a także działania likwidujące ostatnie zdobycze z 1956 roku na polu kultury, nauki i sztuki oraz niejawne i niejasne rozgrywki frakcyjne w kierownictwie PZPR. Polska była wówczas areną zakulisowej walki politycznej prowadzonej przez „partyzantów”, którym patronował minister spraw wewnętrznych gen. Mieczysław Moczar, z grupą Władysława Gomułki oraz z koterią "śląską", upatrującą przyszłego szefa partii w osobie Edwarda Gierka - I sekretarza Komitetu Wojewódzkiego PZPR w Katowicach.

\footnotetext{
${ }^{13}$ Ibidem, s. 14.

${ }^{14}$ A. Wróblewski: Być Żydem...Rozmowa z Dagiem Halvorsenem o Żydach i antysemityzmie Polaków, Warszawa 1992, s. 213.
} 
Pewną naiwność i swoisty brak politycznej wyobraźni młodzieży w sposób instrumentalny i cyniczny postanowili wykorzystać do realizacji własnych celów skupieni wokół gen. Moczara „partyzanci”. Ich nazwa wzięła się stąd, iż wielu z nich - podobnie jak i ich lider - w czasie II wojny światowej walczyło w Polsce w szeregach komunistycznej partyzantki. W 1968 roku „partyzanci” zręcznie rozegrali sprawę inscenizacji w warszawskim Teatrze Narodowym Dziadów Adama Mickiewicza. Władze zdecydowały się ten spektakl jako antyrosyjski, a nawet ... antyradziecki zdjać ze sceny.

Wieczorem 30 stycznia 1968 roku odbyło się ostatnie przedstawienie, po którym grupa studentów - chcąc zaprotestować przeciwko decyzji władz - zorganizowała uliczną manifestację. Przed teatrem uformował się szacowany na 200-300 osób pochód, który skierował się $\mathrm{w}$ stronę pobliskiego pomnika Mickiewicza, gdzie złożono kwiaty $\mathrm{w}$ barwach narodowych oraz przyniesiony transparent. Praktycznie już po zakończeniu demonstracji do akcji wkroczyła milicja, która przy użyciu pałek rozproszyła zgromadzenie. Zatrzymano wówczas 35 osób.

Po kilku tygodniach $\mathrm{z}$ naruszeniem obowiązujących $\mathrm{w}$ tym zakresie wówczas przepisów usunięto z Uniwersytetu Warszawskiego dwóch studentów: Adama Michnika i Henryka Szlajfera. Wśród różnych mniej czy bardziej sensownych - zarzutów, jakie im stawiano, był i ten, że nazajutrz po ostatnim spektaklu Dziadów o przebiegu ulicznej manifestacji i brutalnej interwencji milicji poinformowali korespondenta „Le Monde" Bernarda Margueritte. Jego relacja za pośrednictwem Radia Wolna Europa dotarła z powrotem do Polski, co bardzo nie spodobało się Gomułce i jego najbliższemu otoczeniu.

Koledzy relegowanych studentów w imię solidarności wystąpili $\mathrm{w}$ ich obronie, organizując 8 marca na dziedzińcu uczelni wiec, w trakcie którego potępili też decyzję o zdjęciu ze sceny Teatru Narodowego Dziadów oraz udzielili poparcia potępiającej to posunięcie i - szerzej - krytykującej politykę kulturalną władz rezolucji uchwalonej 29 lutego w czasie Nadzwyczajnego Walnego Zebrania Oddziału Warszawskiego Związku Literatów Polskich. Gdy przyjęto rezolucje studenckie i wiec w zasadzie już się kończył, zebrani zostali brutalnie zaatakowani pał- 
kami przez przybyły na teren Uniwersytetu Warszawskiego tzw. aktyw robotniczy oraz zwarte oddziały Milicji Obywatelskiej.

Konflikt, który zapewne można było jeszcze zażegnać środkami politycznymi, nabrał dramatycznego, choć na szczęście nie krwawego wymiaru (nikt nie został zabity). Przez trzy tygodnie miały miejsce solidarnościowe wystąpienia studentów w szkołach wyższych niemal w całej Polsce. Starcia uliczne między młodzieżą a "siłami porządkowymi” miały wtedy miejsce w kilkunastu miastach w całym kraju. Studencka rewolta, w którą zaangażowało się łącznie kilkadziesiąt tysięcy osób, z czego - jak oficjalnie poinformowano - 2730 zostało zatrzymanych przez milicję, objęła w praktyce wszystkie cywilne uczelnie w Polsce.

W wyniku „wydarzeń marcowych” pozycja Gomułki przejściowo uległa osłabieniu, ale jednak mimo wszystko udało mu się utrzymać u władzy. Niewątpliwie pomogły mu w tym wydarzenia na arenie międzynarodowej, a zwłaszcza - paradoksalnie - Praska Wiosna. I sekretarz KC PZPR od początku z rezerwą i niechęcią odnosił się do tego reformatorskiego eksperymentu, którego celem było stworzenie „socjalizmu z ludzką twarzą". Uważał, iż ta „rewizjonistyczna zaraza” zagraża Polsce i obawiał się, że - wykorzystując niestabilną sytuację polityczną w Czechosłowacji - Zachód mógłby próbować „wyłuskać ją z socjalistycznej wspólnoty”. Obawiał się także, iż RFN mogłaby wykorzystać powstałe zamieszanie na arenie międzynarodowej i przy okazji (jakby w cieniu wydarzeń w Czechosłowacji) podjąć próbę oderwania od Polski ziem przyłączonych do jej terytorium w następstwie II wojny światowej. Mniej przy tym było ważne to, na ile tego typu rachuby w ogóle były realne, niż to, że RFN nie uznawała jeszcze wówczas polskiej granicy zachodniej na Odrze i Nysie Łużyckiej.

Obok przywódcy Niemieckiej Republiki Demokratycznej Waltera Ulbrichta był więc Gomułka tym komunistycznym przywódca, który najaktywniej i najusilniej przekonywał Leonida Breżniewa o potrzebie postawienia tamy „kontrrewolucji” w Czechosłowacji. Na posiedzeniu Biura Politycznego KC PZPR 5 lipca Gomułka nie krył rozczarowania postawą Moskwy. Przekonywał towarzyszy, że Rosjanie robią „to wszystko w rękawiczkach. Gdyby to zależało od nas, to już bym ich dawno złamał. [...] Proces prowadzi do odpadnięcia Czechosłowacji 
z naszego obozu. [...] Widzę trudności z wejściem wojsk obecnie. Radzieccy mają prawo, ponieważ wyzwolili Czechosłowację, zginęły tysiące ich żołnierzy, udzielali pomocy gospodarczej. [...] Możemy radzieckim powiedzieć, że wprowadzimy nasze wojska, bo tu idzie o nasze bezpieczeństwo. Do diabła z suwerennością. Jeśli zaś nie chca, to niech ustępują dalej"15.

Ostatecznie - jak wiadomo - 20 sierpnia późnym wieczorem rozpoczęła się zbrojna interwencja wojsk Układu Warszawskiego w Czechosłowacji, w której m.in. udział wzięło ponad 24 tys. polskich żołnierzy wyposażonych w 647 czołgów, 566 transporterów, 191 dział i moździerzy, 84 działa przeciwpancerne, 96 dział przeciwlotniczych, 4798 samochodów i 36 śmigłowców $^{16}$. Po II wojnie światowej wojska polskie poza granicami kraju nigdy i nigdzie nie były zaangażowane $\mathrm{w}$ takiej skali. Podobnych środków użyto tylko do tłumienia robotniczego buntu na Wybrzeżu w grudniu 1970 roku, a jeszcze większych w czasie operacji wprowadzania stanu wojennego jedenaście lat później.

Odnosząc się do pytań postawionych w tytule niniejszego artykułu należy stwierdzić, że w 1968 roku w Polsce rzeczywiście mieliśmy do czynienia zarówno z poważnym kryzysem społecznym, jak i kryzysem władzy, a może raczej, ściślej rzecz ujmując, kryzysem przywództwa w PZPR. W wyniku ataku ze strony „partyzantów” pozycja Gomułki na pewien czas uległa osłabieniu, choć tak naprawdę nie wiemy, czy celem Moczara było zajęcie jego miejsca, czy też - jak to obrazowo ujmował członek Biura Politycznego i zarazem przewodniczący Rady Państwa Edward Ochab - pragnął być tylko pierwszym po pierwszym sekretarzu. W głośnej rozmowie z Teresą Torańską Ochab stwierdził, że Moczar chciał, aby „Gomułka firmował wszystko formalnie, a on by faktycznie wszystkim kierował. Taka by mu rola odpowiadała [...]"17.

Niezależnie od tego, faktem pozostaje, że wielu uczestników wspomnianej „rewolucji czterdziestolatków” aż do końca istnienia

\footnotetext{
${ }^{15}$ J. Eisler: Notatki Stanisława Trepczyńskiego z posiedzeń Biura Politycznego KC PZPR dotyczące wydarzeń w Czechosłowacji w 1968 roku, w: Wokót praskiej wiosny. Polska i Czechosłowacja w 1968 roku, red. Ł. Kamiński, Warszawa 2004, s. 190.

${ }^{16}$ L. Pagórek: Polska a "Praska Wiosna”. Udział Wojska Polskiego w interwencji zbrojnej w Czechosłowacji w 1968 roku, Warszawa 1998, s. 232.

${ }^{17}$ T. Torańska: Oni, Warszawa 1997, s. 119.
} 
w Polsce realnego socjalizmu piastowało różne wysokie stanowiska partyjne i państwowe. Jednocześnie - jak już wspomniano - wielu studenckich uczestników Marca znalazło się później w kręgu opozycjonistów i aktywnie brało udział w walce z niedemokratyczną władzą. Nie jestem jednak pewien, czy mimo wszystko można by dopatrywać się w wydarzeniach 1968 roku punktu zwrotnego, momentu, od którego zaczęła się powolna agonia systemu. Wydaje się, że w wypadku polskim takim punktem zwrotnym była jednak wielka fala strajkowa z lata 1980 roku i powstanie w jej następstwie "Solidarności" - pierwszej w bloku radzieckim działającej jawnie i legalnie, masowej organizacji niezależnej od władz partyjno-państwowych.

\section{Abstract \\ 1968 in Poland - crisis of authorities, crisis of the society, the beginning of the changes?}

The fundamental question articulated in the article addresses the issue of whether what happened in Poland in 1968 was a social crisis, and if it was, what its background was and what its specific features were? Can we, and should we, thus refer to a crisis of the then authorities? And what did it mean, in general, under the actual conditions of real socialism? And finally, can one say that 1968 marked the beginning of the systemic changes? Pointing out that, in Poland, this process was, by its nature, multi-faceted, the author is of the opinion that, a term inadequate as far as its logic is concerned, namely, 'Marches ' 68 ' (that is, plural rather than singular) should be applied, bearing in mind that this concept encompassed several diverse, not necessarily inter-related, and sometimes even mutually exclusive and contrary strands. An opinion is voiced that the 'March events' also contributed to the formation of something which may be symbolically referred to as 'the ' 68 generation', consisting of the 20-year old youths who were then students. The circumstances of the student protests in Poland, differing from those in the West, are emphasised. The author also maintains that the then events in Poland may be possibly compared to the Prague Spring and the Czech reform movement alone. Recapitulating, the author posits that what happened in 1968 in Poland was both a serious social crisis and a crisis of authority, or perhaps, more precisely, a crisis of leadership in the PUWP. 